\title{
Bacterial Necrotizing Dermohypodermitis (BNDH) and Necrotizing Fasciitis (NF) in Surgical Area at CHU-Kara (Togo)
} \author{
Dosseh David ${ }^{1,2}$ \\ ${ }^{1}$ Department of General Surgery, teaching hospital of Kara , CHU-Kara, Togo \\ ${ }^{2}$ Department of General Surgery, CHU-Sylvanus Olympio de Lomé, Togo \\ ${ }^{3}$ Department of dermatology, teaching hospital of Kara, CHU-Kara, Togo
}

Dossouvi Tamegnon ${ }^{1 *}$, Amavi Ayi ${ }^{2}$, Mouhari-Toure Abas ${ }^{3}$, Amouzou Efoe-Ga ${ }^{1}$, Moumouni Abd-el Kader ${ }^{1}$ and

Received: July 26, 2018; Published: September 21, 2018

*Corresponding author: Dossouvi Tamegnon, General Surgeon, Department of General Surgery, CHU-Kara, Togo, Email: dboris@ymail.com

\begin{abstract}
The necrotizing fasciitis is a serious infection which may affect any part of the body. However, inferior limbs are mostly concerned. The objective of our study is to define epidemiological, clinical and evolution of BNDH-NF in general surgery department of Kara-CHU (Togo). We have unregistered 56 case of BNDH and 20 cases of NF. Neglected traumatic injury is the main predisposing factor of necrotizing fasciitis in our study. The diagnosis is mainly clinical, but the use of computed tomography allowed to assess lesion extension. Early surgical debridement is a key factor for successful recovery.
\end{abstract}

Keywords: Fournier's gangrene; Necrotizing fasciitis; Inferior limb; Computed tomography; Surgical debridement

\section{Introduction}

Bacterial dermo-hypodernitis are infection of the deep skin layers (dermis and hypodermis) that include non-necrotizing infections (mainly erysipelas) and necrotizing infections characterized by dermis, hypodermis and deep facia necrosis in case of necrotizing fasciitis. Although there is currently no consensus about the treatment of these infections, it is generally recognized that bacterial necrotizing dermohypodermitis and necrotizing fasciitis (BNDH-NF) are serious infections that may be life-threatening and required emergency medico-surgical treatment. Epidemiologic data about these serious infections are nearly inexistent. In occidental countries, BNDH-NF are rare with incidence of 1 case for 1,00,000. In sub-Saharan Africa, studies on BNDH are rare and focus on non-necrotizing infections in hospital medical ward in the big cities (capitals). Data are nearly inexistent in secondary cities where the people have rural activities. The objective of our study is to define epidemiology, clinical characteristics and outcome of BNDH-NF in general surgery ward of Kara-CHU (Togo).

\section{Methodology}

This study is a retrospective study based on the files of all patients admitted for BNDH and NF in general surgery ward of Kara CHU from January $1^{\text {st }}, 2014$ to October 31 2016 (34 months period). Kara CHU is a reference center of the North part of Togo and the population is mainly rural. All the files of patients diagnosed with BNDH-FN were included in the study. The diagnosis of BNDH-FN was clinical and based on the aspect of surgical excision (extension to the deep fascia) [1].

Study parameters were sociodemographic (age, gender, profession), clinical data (time to admission, medical history, general examination, route of entry of the infection, topography), complementary exam (complete blood count, erythrocyte sedimentation rate, bacteriology of samples), treatment and outcome.

Time to admission was the time between the beginning of the symptoms and admission to surgery ward [2].

When the deep fascia was not involved in the surgical excision, the diagnosis was BNDH. When the deep fascia was involved, the diagnosis was NF [3]. Necrotizing lesion of perineum and scrotum were classified as Fournier gangrene. All the files were manually processed and registered in a database. The data were analyzed using épi info software. The data were anonymized in the database.

\section{Results}

Over the 34 months of the study, 86 cases of BNDH-NF out of 1285 patients hospitalized (frequency of $6.7 \%$ ) were admitted in the general surgery ward of Kara CHU (56 cases of NF 20 cas of BNDH and 10 cases of Fournier gangrene). The number of 
cases was high between May and October Figure 1. There were 54 males and 32 females (sex ratio 1,7). Mean age was 55,6 years (from 17 to 88-year-old). The profession of the patients was mainly farmer $(53,5)$, then housekeeper $(38,4 \%)$ (Table 1$)$.

Table 1: Distribution of patients by profession.

\begin{tabular}{|c|c|c|}
\hline & Number & Percentage (\%) \\
\hline Farmer & 46 & 53,5 \\
\hline Housekeeper & 33 & 38,4 \\
\hline Builder & 2 & 2,3 \\
\hline Carpenter & 1 & 1,2 \\
\hline Welder & 1 & 1,2 \\
\hline Merchant & 1 & 1,2 \\
\hline Military & 1 & 1,2 \\
\hline Student & 1 & 1,2 \\
\hline Total & 86 & 100 \\
\hline
\end{tabular}

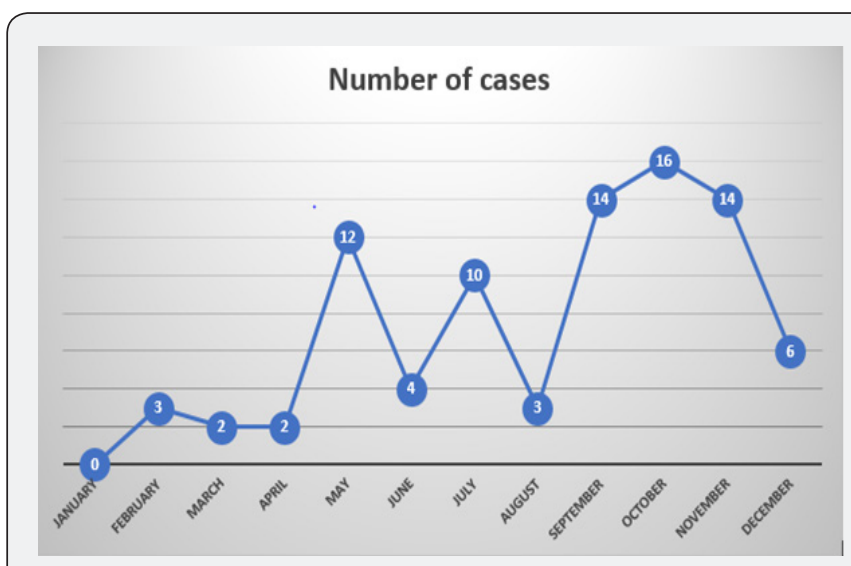

Figure 1: Distribution of the number of patients by month. There were 54 males and 32 females (sex ratio 1,7). Mean age was 55,6 years (from 17 to 88 -year-old). The profession of the patients was mainly farmer $(53,5)$, then housekeeper $(38,4 \%)$.

Table 2: Admission medium and medical history of patients.

\begin{tabular}{|c|c|c|c|}
\hline \multirow{4}{*}{ Admission Medium } & & Number (N=86) & Percentage (\%) \\
\hline \multirow{4}{*}{ Medical History } & Referred or transferred & 10 & 11,6 \\
\cline { 2 - 4 } & Direct admission through emergency unit & 76 & 88,4 \\
\cline { 2 - 4 } & No medical history & 63 & 73,3 \\
\cline { 2 - 4 } & Arterial hypertension & 15 & 17,4 \\
\cline { 2 - 4 } & HIV infection & 5 & 5,8 \\
\cline { 2 - 4 } & Toes intertrigo & 3 & 3,5 \\
\cline { 2 - 4 } & Lower limb lymphoedema & 2 & 2,3 \\
\cline { 2 - 4 } & Diabetes & 2 & 2,3 \\
\cline { 2 - 4 } & Outoesity & 10 & 1,2 \\
\hline
\end{tabular}

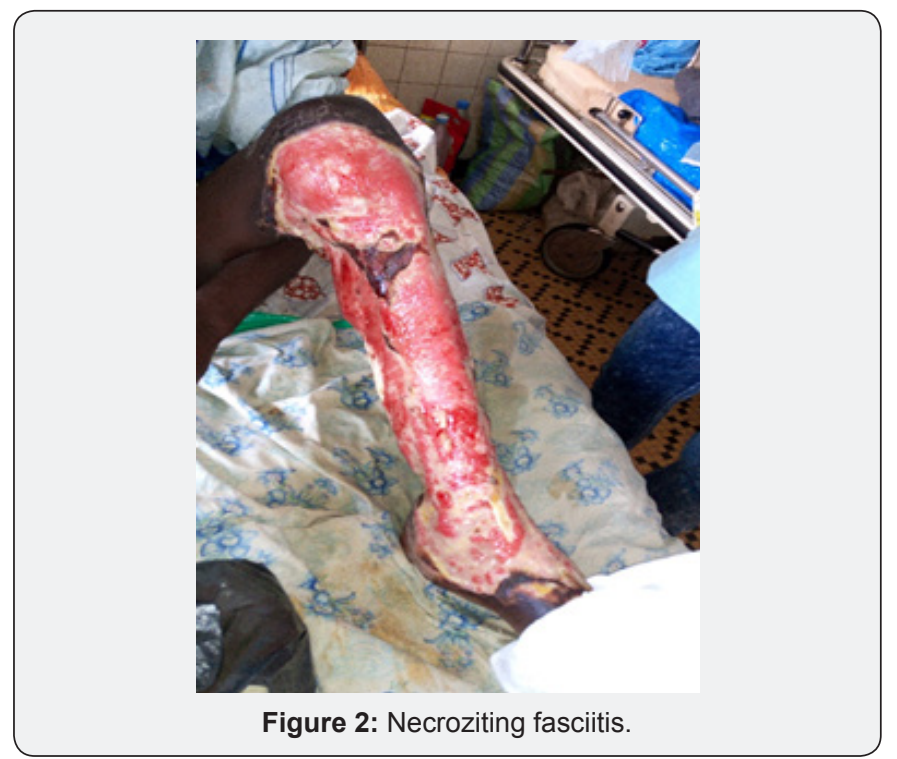

The mean time to admission was 7 days (5 to 21 days) [4]. Most of the patient $(n+76)$ were auto medicated and the others $(n=10)$ had a previous medical consultation before being transferred or referred. Ten patients took at least a NSAID before admission. Most of the patient $(\mathrm{n}=63)$ did not have any relevant medical history [5] (Table 2) (Figure 2).

Table 3: Admission medium and medical history of patients.

\begin{tabular}{|c|c|c|c|}
\hline & & Number & Percentage (\%) \\
\hline \multirow{3}{*}{ FN } & lower limbs & 51 & 59,3 \\
\hline & $\begin{array}{c}\text { facial cervical } \\
\text { thoracic }\end{array}$ & 2 & 2,3 \\
\hline & upper limbs & 3 & 3,5 \\
\hline \multirow{2}{*}{ DHBN } & Lower limbs & 19 & 22,1 \\
\hline & Upper limbs & 1 & 1,2 \\
\hline $\begin{array}{l}\text { Fournier } \\
\text { Gangrene }\end{array}$ & $\begin{array}{l}\text { Perineum and } \\
\text { scrotum }\end{array}$ & 10 & 11,6 \\
\hline \multicolumn{2}{|c|}{ Total } & 86 & 100 \\
\hline
\end{tabular}
bactérienne nécrosante.

Upon admission, all the patients had fever, 6 patients had alteration of general state $(6.9 \%)$ of which 4 had HIV infection, 7 patients had septic shock (8.1\%). Except Fournier gangrene localized on perineum and external genital organs, other localization was on the lower limbs [6] (Table 3). 
The route of bacterial entry was found in 45 cases (52.3\%). This was lower limbs injury in 38 cases (neglected traumatic injury in 35 cases [7], toes intertrigo in 3 cases), upper limbs injuries in 4 cases (all were neglected traumatic injuries), dental abscess in 2 cases (NF cacio-cervico-thoracic) and 1 case if anal fistula in a patient with Fournier gangrene [8] (Figure 3).

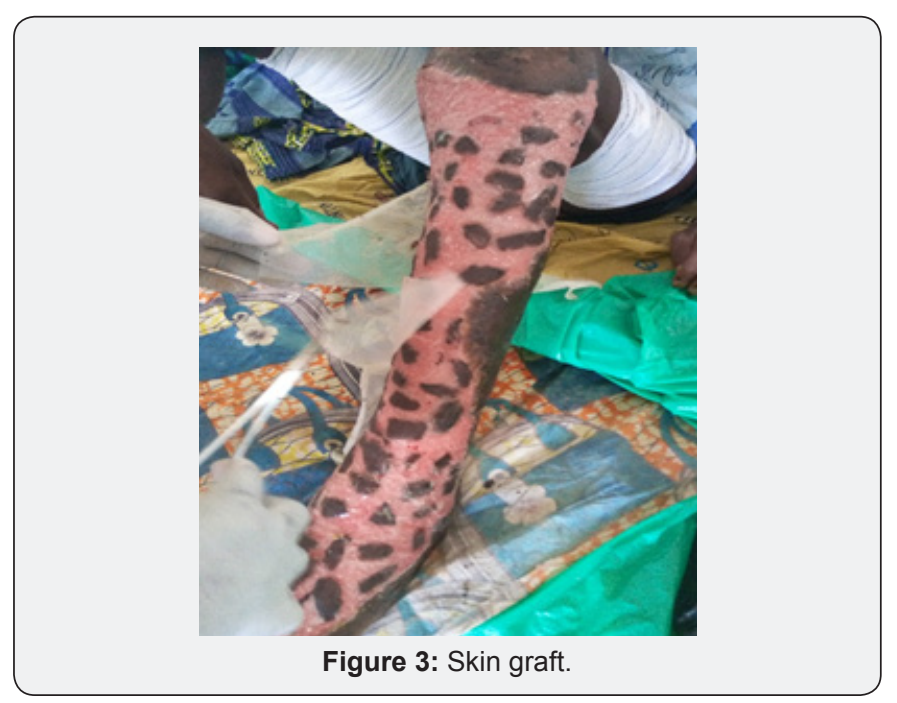

One-hundred percent of patient had polynuclear neutrophils hyperleukocytosis associated to anemia requiring blood transfusion in 46 patients (53.5\%) [9]. Erythrocyte sedimentation rate was upper to $20 \mathrm{~mm}$ after 1 hour in all patients. Escherichia coli was found in 2 cases and Staphylococcus aureus in 6 cases. The laboratory did not find any germ in the other patients [10].

The treatment was surgical excision in 79 cases (91.9\%), associated to antibiotic treatment against streptococcus, staphylococcus and anaerobic bacteria. Dressing was done every day and then every 48 hours depending on the outcome of ulceration. Among the patient who had surgery, 51 (all with NF) had pinch skin graft to improve healing [11].

The outcome was favorable in all patients except 6 that presented graft necrosis. However, simple local treatment allowed a good healing. There was one leg amputation due to gas gangrene and 6 patients died due to shock upon admission (5 cases of NF and 1 case of Fournier gangrene). Mean hospitalization duration was 30 days [12].

\section{Discussion}

This study described the characteristics of BNDH-NF in 86 patients admitted in general surgery ward of Kara CHU. BNDHFN were mainly observed in farmers and housekeepers, mainly in the lower limbs with a traumatic injury as bacterial entry. His is the first study describing BNDH-NF in surgical ward dealing mainly with rural population.

The frequency of these serious infection in our study was high (86 cas over 3 years) and differ from the published data from sub-Saharan Africa. In Lomé (Togo), Saka et al reported 7 cases over 11 years in dermatology and internal medicine wards; in Conakry, Cissé $\mathrm{M}$ et al. [7] reported 31 cases over 4,5 years in the dermatology ward of CHU Donka; and in Dakar, Diédhiou et al. [8] reported 58 cases over 5 years in internal medicine ward [1] (Figure 4).

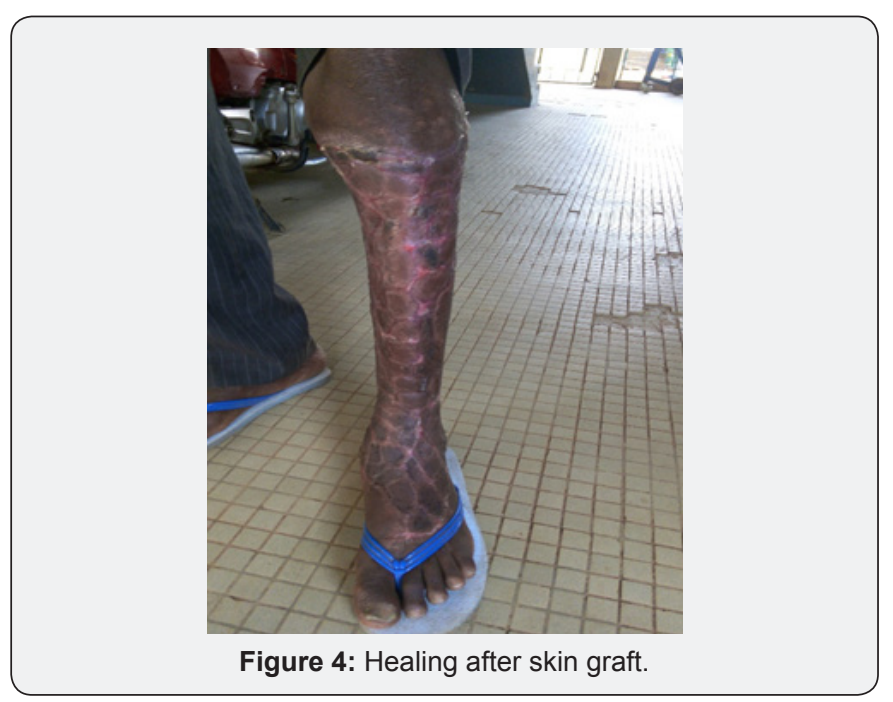

The high frequency of BNDH-NF, mainly localized to the lower limbs, in our study may be explained by the lack of use of protection by the farmers (boots to work in the fields) [1317]. Additionally, there was lack of care about injuries, high level of auto medication (use of cataplasm on injury that may induce infections) and socioeconomical precarity of these population that lead to consult traditional therapist (In Togo, only state workers have a mandatory medical insurance). The mean age of the patients in our study was 55 years old. This is in accordance with literature data (age from 55 to 65 years old). There were no gender differences.

Several predisposing factors were found in our study: neglected traumatic injuries, obesity, diabetes, toes intertrigo, lymphoedema. These predisposing factors were previously reported in scientific literature. A study performed in subSaharan Africa by Pictché et al. [9] found that obesity lymphoedema, cosmetic depigmentation and toes intertrigo are predisposing factor for erysipelas and consequently NF. This was confirmed by the study of El Bakali et al. [13].

NF diagnosis is clinical. NF are polymicrobial, but the most frequently isolated germ is group A beta-hemolytique streptococcus [18]. However, this is not in accordance with the results of our study. Usual biological exam did not provide more information but allow to assess the consequence of the disease on the general state. Local and blood bacterial sampling should be performed to identify the germ and adapt antibiotic treatment.

The place of imagery is important in the treatment of NF. $\mathrm{X}$-ray allow to show gas in soft tissue case of gas gangrene. Tomodensitometry and MRI are more performing, showing fasci thickening, fat heterogeneity and presence of gas [19]. However, MRI is generally not available in an emergency. In this study, the 
patients were treated based on clinical data, because imagery is too expensive for our patients.

Treatment of necrotizing fasciitis is based on surgery, anti-biotherapy and resuscitation. This is a multidisciplinary treatment that required the involvement of surgeon, anesthetist and infectiology's to be effective.

Early surgery is major in the treatment with complete removal of necrotizing tissues or amputation in case of gas gangrene. Antibiotic treatment is the second important point. NF is polymicrobial and bacterial sample is often without findings. Triple antibiotic treatment is required to stop infection. Antibiotherapy should associate betalactamines, amino side and imidazole [20,21]. This may depend on the severity of the infection. The choice may be done by an infectiology's with a good experience. However, there is no infectiology's in Togo. In our study, most of the patient received probabilistic treatment with ceftriaxone, metronidazole and gentamicin by parenteral route and then amoxicillin-clavulanic acid or macrolide by oral route of the infection state decreased. The results were satisfying (Figure 5).

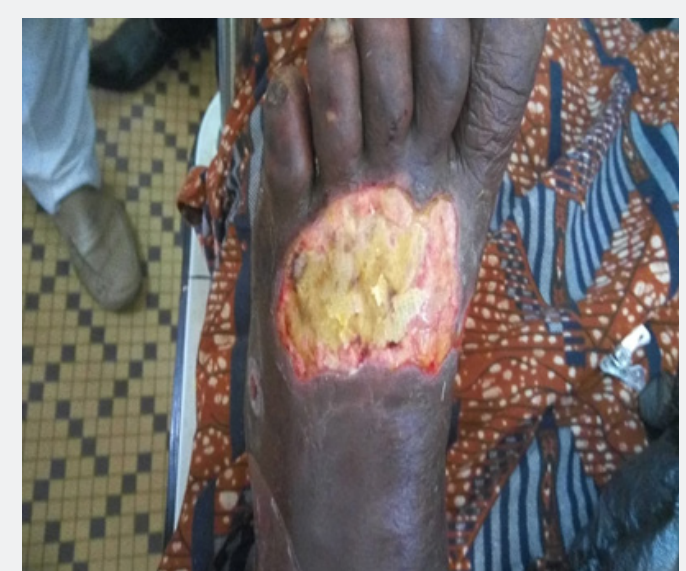

Figure 5: Bacterial necrotizing demohypodermitis.

Then resuscitation unit should manage surgery and antibiotic treatment for better results because the patients required hemodynamic, metabolic, nutritional and analgesic support. Hyperbaric oxygen therapy is an adjuvant treatment in NF but is only proved to be effective in clostridium gangrene.

\section{Conclusion}

Necrotizing fasciitis are rare but serious, because they may be life-threatening and may lead to disability. Neglected traumatic injuries was a major predisposing factor in the context of our study. Treatment is multidisciplinary but early surgery is major in treatment successfulness.

\section{References}

1. (2001) French society of dermatology. Consensus meeting: Erysipelas et necrotizing fasciitis: Treatment. Ann Dermatol Venereol 128: 458482.
2. Bisno AL, Stevens DL (1996) Streptococcal infections of skin and soft tissues. N Engl J Med 334: 240-245.

3. Lancerotto L, Tocco I, Salmaso R, Vindigni V, Bassetto F (2012) Necrotizing fasciitis: classification, diagnosis, and management. J Trauma Acute Care Surg 72(3): 560-566.

4. Droitcourt C, Bourgault Villada I, Chosidow O (2013) Bacterial necrotizing dermohypodermitis and necrotizing fasciitis. Réanimation 10: 276-281.

5. Kaul R, McGeer A, Low DE, Green K, Schwartz B (1997) Populationbased surveillance for group A streptococcal necrotizing fasciitis: Clinical features, prognostic indicators, and microbiologic analysis of seventy-seven cases. Ontario Group A Streptococcal Study. Am J Med 103(1): 18-24.

6. Eke N (2000) Fournier's gangrene: a review of 1726 cases. Br J Surg 87(6): 718-728.

7. Cisse M, Keita M, Toure A, Camara A, Machet L, et al. (2007) Bacterial necrotizing ermohypodermitis: retrospective and monocentric study of 244 cases observed in Guinee. Ann Dermatol Venereol 134: 748-751.

8. Diédhiou D, Leye MMM, Touré M, Boiro D, Sow D, et al. (2013) Bacterial necrotizing dermohypodermitis in Dakar: Retrospective of 194 cases treated Internal medecine at Clinique Médicale II. CAMES 's Journal: Science of wealth 1: 31-35.

9. Pitche P, Diatta B, Faye O, Diane BF, Sangare A, et al. (2015) Risk factor associated to leg's erysipelas in Africa subsaharina: monocentric casecontrol study. Ann Dermatol Venereol 142(11): 633-638.

10. Pitche P, Tchangai Walla K (1997) Erysipelas in hospital area in Lome (Togo). Bull Soc Pathol Exot 90: 189-191.

11. Saka B, Kombate K, Mouhari Toure A, Akakpo S, Boukari T, et al. (2011) Bacterial Necrotizing dermohypodermitis and necrotizing fasciitis: 104 cases series from Togo. Med Trop (Mars) 71(2): 162-164.

12. Mouhari Toure A, Kombate K, Saka B, Akakpo S, Boukari OB, et al. (2010) Auto medication in dermatologic diseases in Lomé. Med Trop 70: 303-304.

13. EL Bakali A, Yazidi A, Senouci K, Bennouna biaz F (1995) Necroziting fasciitis associated with non-steroidal anti-inflammatory drugs. Médecine of Maghreb 50: 6-8.

14. Green LG, Dafoe DC, Raffin TA (1996) Necrotizing Fasciitis. Chest 110: 219-229.

15. Melene F (1924) Hemolytic streptococcus gangrene. Arch Surg 9(2): 317-364.

16. Rajan DK, Scharer KA (1998) Radiology of Fournier's gangrene. AJR Am J Roentgenol 170: 163-168.

17. Schmid MR, Kossmann T, Duewell S (1998) Differentiation of necrotizing fasciitis and cellulitis using MR imaging. AJR Am J Roentgenol 170: 615-620.

18. Smeets L, Bous A, Lecoq JP, Damas P, Heymans 0 (2006) Rev Med Liege 61(4): 240-244.

19. Childers BJ, Potyondy LD, Nachreiner R, Rogers FR, Childers ER, et al. (2002) Necrotizing fasciitis: a fourteen-year retrospective study of 163 consecutive patients. Am Surg 68(2): 109-116.

20. Elliott DC, Kufera JA, Myers RA (1996) Necrotizing soft tissue infections. Risk factors for mortality and strategies for management. Ann Surg 224: 672-683.

21. Demello FJ, Haglin JJ, Hitchcock CR (1973) Comparative study of experimental Clostridium perfringens infection in dogs treated with antibiotics, surgery, and hyperbaric oxygen. Surgery 73(6): 936-941. 

(CC) (i) This work is licensed under Creative

BY DOI: 10.19080/OAJS.2018.09.555772
Your next submission with Juniper Publishers will reach you the below assets

- Quality Editorial service

- Swift Peer Review

- Reprints availability

- E-prints Service

- Manuscript Podcast for convenient understanding

- Global attainment for your research

- Manuscript accessibility in different formats ( Pdf, E-pub, Full Text, Audio)

- Unceasing customer service

Track the below URL for one-step submission https://juniperpublishers.com/online-submission.php 